al-Ihkam: Jurnal Hukum dan Pranata Sosial, 15 (1), 2020: 93-116

ISSN: 1907-591X, E-ISSN: 2442-3084

DOI: http://doi.org/10.19105/al-ihkam.v15i1.3083

\title{
Resistance Strategies of Madurese Moslem Women Against Domestic Violence in Rural Society
}

\author{
Fahruddin Ali Sabri \\ Faculty of Ushuluddin and Dakwah, IAIN Madura, \\ Jl. Raya Panglegur, Km. 04 Tlanakan, Pamekasan 69371 \\ Email:didin021@gmail.com \\ Arif Wahyudi \\ Faculty of Ushuluddin and Dakwah, IAIN Madura, \\ Jl. Raya Panglegur, Km. 04 Tlanakan, Pamekasan 69371 \\ Fatekhul Mujib \\ Charles University, Prague, Opletalova 38, 11000 Staré Město, Ceko
}

Article history: Received: 16 Desember 2019, Accepted: 10 Maret 2020, Published: 27 Juni 2020

\begin{abstract}
:
Although regarded as weak, helpless and vulnerable for violence, some rural Madurese women are no longer silent and passive in coping with domestic violence they experience. This study aims to identify the survivors' experiences and choices they made as resistance strategies to reduce or end the violence. The focus was on whether the choices fit with sharia teaching. The study uses empirical legal research and anthropological theory of law and figh approach to analyze data. It finds that women who try to take a dispute resolution process show their active attitude and courage to voice injustice, discomfort or disagreement in their domestic life. Some of their strategies fit with shariah teaching while others do not so. However anthropologically, their choice to stop the violence is for the sake of maintaining their marital relation. In the legal sub-culture, they have well considered potential profits and losses as well as the needs or interests they want to get.
\end{abstract}

Author correspondence email: didin021@gmail.com Available online at: http://ejournal.iainmadura.ac.id/index.php/alihkam/ Copyright (c) 2020 by al-ihkam. All Right Reserved 
Fahruddin Ali Sabri, ArifWahyudi, Fatekhul Mujib

\title{
Keywords:
}

Resistance Strategies; Sub Legal Culture; Domestic Violence; Islamic Legal Maxim

\begin{abstract}
Abstrak:
Beberapa perempuan Madura yang tinggal di pedesaan sudah tidak lagi menunjukkan sikap diam dan pasif dalam menghadapi kekerasan dalam rumah tangga. Meskipun pada awalnya mereka dianggap sebagai manusia yang lemah, tidak berdaya dan rentan mengalami kekerasan. Studi ini bertujuan untuk mengidentifikasi apakah pengalaman dan pilihan-pilihan strategi perlawanan yang dibangun oleh penyintas KDRT sesuai dengan ajaran syariah atau tidak, dan untuk mengidentifikasi keefektifan strategi perlawanan yang dilakukan untuk mengurangi maupun mengakhiri kekerasan. Studi ini berjenis penelitian hukum empiris dan menggunakan teori antropologi hukum dan pendekatan kaidah fiqih untuk menganalisa data. Ketika perempuan berusaha untuk melakukan proses penyelesaian KDRT, hal ini telah menunjukkan sikap aktif dan keberaniannya untuk menyuarakan ketidakadilan, ketidaknyamanan maupun ketidaksepakatan dalam menjalani kehidupan rumah tangganya. Strategi perlawanan yang mereka lakukan ada yang sesuai dengan syariat Islam dan ada yang bertentangan. Namun secara antropologis, mereka memiliki pilihan untuk menghentikan kekerasan dengan latarbelakang kepentingan dan kekuasaan untuk mempertahankan hubungan pernikahannya. Secara sub budaya hukum, mereka telah mempertimbangkan untung rugi, kebutuhan maupun kepentingan apa yang ingin didapatkan.
\end{abstract}

Kata Kunci:

Strategi Perlawanan; Sub Budaya Hukum; Kekerasan Dalam Rumah Tangga; Kaidah Fikih 


\section{Introduction}

Every existing law and legal must have provided surveillance and measures on violence against women. The number of reported domestic violence cases in Indonesia increases every year. It reached 5,114 in last 2019. ${ }^{1}$ A year before, divorce cases due to domestic violence in Pamekasan Religious Court were 77 and Sumenep with 53.2

The numbers clearly show that domestic violence against women does still occur in Madura. Domestic violence victims should get shelter from legal structures to protect them from any further violence. State and society must actively participate to make conflict resolution between victims and perpetrators. Moreover, the victims are always in weak and helpless condition in their household relationship. ${ }^{3}$

Women, elderly, children, the poors, persons with disabilities, prisoners, minority groups, domestic refugees, migrant workers and their children, including those without official citizenship documents or any companion, indigenous people, ${ }^{4}$ homosexuals and people with HIV/AIDS 5 are vulnerable to violence. The violence can be through discriminatory and inhumane treatment, as well as the access restriction on their basic human rights.

This study aims to identify and uncover experiences as well as choices of resistance strategies developed by survivors of domestic violence in protecting their human rights. It will show whether the strategies fit with sharia teachings or not. Additionally, this also

${ }^{1}$ Komnas Perempuan, "Korban Bersuara, Data Bicara Sahkan Ruu Penghapusan Kekerasan Seksual Sebagai Wujud Komitmen Negara Catatan Kekerasan Terhadap Perempuan Tahun 2018" (Jakarta, 6 Maret 2019), 11.

2 Unpublished data.

${ }^{3}$ Badriyah Khaleed, Penyelesaian Hukum KDRT: Penghapusan Kekerasan dalam Rumah Tangga dan Upaya Pemulihannya (Yogyakarta: Pustaka Yustisia, 2015), 51.

${ }^{4}$ HAM Komnas, "Laporan Tahunan Komnas HAM 2016: Pemenuhan Hak Kelompok Minoritas dan Rentan di Indonesia," Jakarta: Komnas HAM, 2017, 13.

${ }^{5}$ Ingrid Nifosi-Sutton, The Protection of Vulnerable Groups under International Human Rights Law (New York: Routledge, 2017), 54. 
wants to identify effectiveness of the strategies to reduce or end the violence. The study involves four respondents who live in rural areas with a wide variety of education and income level.

In a practical way, this study aims to educate domestic violence victims in choosing effective resistance strategies without ignoring religious norms. It also shows how both state and non-state actors should intensely communicate with the victims so that they can literally know the complaints and experiences to draft a strategic index category in order to reduce and eradicate domestic violence in Madura. These important actors should be proactive in service instead of passive and simply waiting for the victims to come.

Several studies have shown that victims of domestic violence in rural areas have carried out several resistance strategies to resolve the problem. One of them discussed the perceptions of American rural women who put up a fight against perpetrators in dealing with domestic violence. They did it by carrying out verbal attacks, holding back the tears, and threating of divorce even asking the court to decide on divorce. ${ }^{6}$ Some others fight the perpetrators by running away, distracting, protesting, quietly accepting, and seeking help. ${ }^{7}$

These strategies sometimes seem to fail in eradicating domestic violence cases because of obstacles in traditional gender roles and social control in rural settings. However, victims typically think that they do the right thing with the strategy especially by considering the existence of women's institutions in the village. 8 This study will look at the same problem through different perspective namely Islamic legal maxim to reveal whether the resistance strategy of the victims fits with Islamic sharia rules.

${ }^{6}$ Kim M Anderson, Lynette M Renner, and Tina S Bloom, "Rural Women's Strategic Responses to Intimate Partner Violence," Health Care for Women International 35, no. 4 (2014): 423-41.

${ }^{7}$ Amir Mohammad Sayem and Mohammad Aftab Uddin Khan, "Women's Strategic Responses to Intimate Partner Violence: A Study in a Rural Community of Bangladesh," Asian Social Work and Policy Review 6, no. 1 (2012): 23-39.

${ }^{8}$ Thelma Riddell, Marilyn Ford-Gilboe, and Bevery Leipert, "Strategies Used by Rural Women to Stop, Avoid, or Escape from Intimate Partner Violence," Health Care for Women International 30, no. 1-2 (2009): 134-59. 
When a victim begins to be pretty sure to fight the violence perpetrators, she will simultaneously try hard to avoid him. She will typically fight back in order to reduce or even reject the violence from those who usually play dominant role ${ }^{9}$ in their domestic relations. The situation in which the victim is eventually able to avoid violence varies one another. Usually, the resistance is only known by the victim while others, including husband or the perpetrator, do not realize her action as a form of resistance. She might secretly borrow a bottle of milk or a slice of bread from her neighbor so that she can avoid asking him for money. This aims to maintain her honor and ensure her safety. ${ }^{10}$

The resistance can take three strategies namely internal, external and interpersonal. Internal resistance is chosen by a victim who tries to defend themselves, get revenge and challenge the financial control of the perpetrators. ${ }^{11}$ Meanwhile, the external is for those who try to access both informal assistance from friends or family and formal one from state or non-state social organization. ${ }^{12}$ As for interpersonal resistance is taken by victims who can engage their interaction with the perpetrators such as threatening to fight or leaving the perpetrator. ${ }^{13}$ These three resistance strategies can also be responses to reject and fight the violence they experience.

In the history of culture, it is possible for every society to experience any disputes among individuals within. They usually have several ways to resolve it depending on internalized culture of each. Some may do it thrung lumping it (leaving a case without any

9James C. Scott, Weapons of the Weak: Everyday Forms of Peasant Resistance (New Haven and London: Yale University Press, 1985), 295.

${ }^{10}$ Mandy Morgan and Tony Mattson, "Dignity, Diversity, and Resistance: A Bicultural, Community-Led Approach to Transforming Social Responses to Domestic Violence in Aotearoa New Zealand," Australian Community Psychologist 29, no. 2 (2018), 8.

${ }^{11}$ Margaret Abraham, Speaking the Unspeakable: Marital Violence among South Asian Immigrants in the United States (New Brunswick, New Jersey and London: Rutgers University Press, 2000), 138.

${ }^{12}$ Abraham, 133.

${ }^{13}$ Noelle M St Vil dkk., "A Qualitative Study of Survival Strategies Used by Low-Income Black Women who Experience Intimate Partner Violence," Social Work 62, no. 1 (2017): 63-71. 
settlement which means acceptance without any demand), avoidance (avoiding, evading or moving away), coercion (coercing forcefully), negotiation, mediation (deliberation facilitated by a mediator), arbitration (arbitration/taking over to a third party as a problem solver) and adjudication. ${ }^{14}$

Practically, the community has two choices in dispute resolution, namely through court and non-court. This shows that anthropologically and sociologically, traditional societies use several methods in resolving disputes without physical violence such as fists, sticks, or poison arrows. Settlement of disputes benefits the community to uncover injustice, discomfort or disagreement in living their daily lives. More than that, dispute resolution can be an entry point to deepen relations among community members in order to achieve lasting harmony. ${ }^{15}$

The disputes resolution in society can be through either voluntarily or involuntarily depending on the intention of involved parties. The voluntary can take negotiation and mediation strategy, while involuntary is through arbitration and adjudication. Negotiations is particularly preferred as it offers of free bargaining principle in which parties are free to determine their interests and power, while adjudication is highly constrained by legal rules and principles. ${ }^{16}$

\section{Research Method}

This is an empirical legal research because it examines the phenomenon of human's religious life in general. Usually, its common approach is historical-empirical instead of doctrinal-normative. ${ }^{17}$

${ }^{14}$ Laura Nader dan Harry F. Todd, Jr., "Introduction: The Disputing Process" in Laura Nader and Harry F Todd, The Disputing Process: Law in Ten Societies (New York: Columbia University Press, 1978), 8-10.

15Jerome $\mathrm{T}$ Barrett dan Joseph Barrett, A History of Alternative Dispute Resolution: The Sory of a Political, Social, and Cultural Movement (San Francisco: John Wiley \& Sons, 2004), 2.

${ }^{16}$ Martin Shapiro, Courts: a Comparative and Political Analysis (London: University of Chicago Press, 1981), 6.

${ }^{17}$ Amin Abdullah, "Relevansi Studi Agama-Agama dalam Milenium Ketiga". In Amin Abdullah, Mencari Islam: Studi Islam dengan Berbagai Pendekatan (Yogyakarta: Tiara Wacana, 2000), 1. 
Additionally, it uses qualitative approach as the research procedure to produce descriptive data both writen and oral resulted from people and observed behavior. This approach leads to research findings out of statistical procedures or other forms of calculation. ${ }^{18}$ The approach is directed mostly to the comprehensive data about background of each interviewee. Therefore, both individuals and organization are not included at the variable or hypotheses, but as a part of a wholeness. ${ }^{19}$

This study uses anthropological theory of law. To avoid ethnocentrism bias, it pays attention to emic (perspective of observed part) and etic (perspective of researcher). ${ }^{20}$ The selection of this method aims to interpret the behavior, actions, and speech, as well as thick description of related events. Furthermore, it records experiences of domestic violence victims in fighting against the violence they experienced. The research took place at Pamekasan Regency.

The primary data of this research is from interviews and observations on domestic violence cases, particularly a case with victim's resistance experience. Meanwhie, secondary data consists of relevant notes relevant to the focus of study, data from research results, journals, archives, personal documents, and various other related literature. This study focused on 4 respondents with a purposive sampling method aiming to enabe in-depth analysis of women's experiences in resisting the violence they experienced.

Interview technique of this research is semi-structured narrative ones. The data from both interview and observation is then analysed using techniques offered by Matthew B. Miles and A. Michael Huberman. Researchers do the analytical process interactively and continuously until the end process to ensure its sufficiency. The analytical process itself has three steps, namely: data reduction, data presentation and drawing conclusions/verification.

\footnotetext{
${ }^{18}$ Anselm Strauss dan Juliet Corbin, Dasar-dasar Penelitian Kualitatif (Yogyakarta: Pustaka Pelajar, 2003), 4.

${ }^{19}$ Lexy J. Moleong, Metodologi Penelitian Kualitatif (Bandung: Remadja Karya, 1989), 4.

${ }^{20 J h o n ~ W ~ C r e s s w e l, ~ P e n e l i t i a n ~ K u a l i t a t i f ~ d a n ~ D e s a i n ~ R i s e t ~(e d i s i ~ b a h a s a ~}$ Indonesia) (Yogyakarta: Pustaka Pelajar, 2015), 134.
} 
This series of cyclical process and interactions at the time before, during, and after proportional data collection to build general insight called analysis. ${ }^{21}$

\section{Research Results and Discussion}

The victims committed several actions as response of domestic vioelnce they experience as well as resistance strategies to the violence perpetrators themselves. They put up a fight as stated more detail in the following interview result:

1. NMH is a housewife who lives in Palengaan Subdistrict, Pamekasan Regency. She got wedded in the local civil registry office or KUA. She recounted her experience of violence and resistance as follows:

"My husband is a freelance worker. Sometimes he does farming, sometimes he works as a construction worker. I do not have my own income. Every day I do houseworks such as sweeping the floor, preparing food, and washing clothes. He rarely helps the household chores. We often fight each others because of trivial matters. When this occured, my husband liked to beat me and made fun of me. At the beginning of marriage, I tried to obey him but now, I do not longer do that because we get separated. My face was bruised from multiple-times hit, but more than that, I feel hurt, a feeling of being hung up by our marital status, miserable, and stressed.

Once a while, when he hit me, I shouted for asking help from neighbors and relatives as they were willing to listen to my stories and complaints about the violence I experienced. Another time, I also had fought him back by throwing plates at him. As a result, he did not hit and scold me as often as before. I decided to come back to my parents'

${ }^{21}$ Matthew B Miles dan A Michael Huberman, Analisis Data Kualitatif transl. Tjetjep Rohendi Rohidi (Jakarta: Penerbit Universitas Indonesia, 1992), 16-21. 
house. I told them about my problem but I did not do the same for my parents in law. A few of neighbors empathize with my domestic violence experience, but most of them tend to be ignorant because they consider domestic violence as a private thing of a a household. Even though I only graduated from junior high school and had studied at Islamic boarding school, I never make a visit to any dukun or kyai (Islamic priest) when dealing with my household problems. Likewise, I did not tell my community leaders, head of the Neighborhood Association or Rukun Tetangga, or the Police about what I experience in domestiv life" ${ }^{22}$

2. $A M N$ is a mother who works as a teacher with monhtly income IDR. 500,000. She lives in Palengaan Subdistrict, Pamekasan Regency. She got bachelor in education and got wedded at the local civil registry office or KUA. She recounted her experience of violence and resistance as follows:

"My husband has a permanent job, but he never helped me to do any housework. However, I was always available for sexual intercourse if he asked me because I think it's my obligation as a wife. I was once beaten by my husband because of a trivial problem and I got my face turned bluish. My husband thinks I am chatty. He also often made fun of me. As a result, I often got panicked and the house felt like a prison. I got divorced but did ruju' (coming back to the old relationship) because of shameness for becoming a widow.

When the violence occurred, I once returned to my parents' home for a month. I filed for divorce but retracted the lawsuit afterward. Now I rarely experience violence from my husband anymore. In

22 NMH, Pamekasan, direct interview, (31 Juli 2019) 
the end, I need to be patient and accept it as a woman's nature. Although I am a university graduate, I have consulted with a dukun and he said that I was affected by pelet. He gave me a spell to read as same as the kyai whom I also consult with and gave some prayers to read" .23

3. WSH is a housewife who lives in Proppo District, Pamekasan Regency. She is an elementary graduate and got wedded at the local civil registry office or KUA. She recounted her experience of violence and resistance as follows:

"My husband does not have any permanent job, but he often wanders and simlply goes outside. If he goes to work, he also does it outside. He never helps me with housework. I do not have my own income. At the beginning of marriage, we fought a lot. I got married through match making process without any love and affection. I once quarreled with him by exchanging hits each others. My left leg had a stab wound and scars until now. My cheek had also been hit by sickles while my feet and back got bruised bluish. I suffer physically and mentally. I fought back for violence I experience hoping that my husband would stop doing it, but he keeps it. Sometimes, I simply did nothing because for fear of being disobedien like when I was thrown from the house to the outside terrace.

Although I get violence, I do not want to be separated from him. I always back down my ego, keep being patient while wishing hat my husband would treat me better. I once ran away to my parents' house and lived there for about 1 month. To deal with this violence, I then went to the dukun who suggested me to mix my menstrual blood into

${ }^{23}$ AMN, Pamekasan, direct interview, (28 Juli 2019) 
his drink. As a result, he no longer behaves rude without any suspicion for the changes he had experienced. I did all this so that I could still maintain my household". ${ }^{24}$

4. EPS is a woman who works as an employee with Rp. 1,000,000 to Rp. 1,500,000 monthly income. She lives in Pegantenan District, Pamekasan Regency with bachelor's education and got wedded at the local civil registry office or KUA. She recounted her experience of violence and resistance as follows:

"My husband has a permanent job and so do I. However, I handle all household matters without his help. I began to complain about his habit of being grumpy, prying up my past, exaggerating trivial problems and such. When this happens, he often hit my face until it got bruised. I reported this incident to the police because I felt scared, ashamed, and hurt. However, he kept doing it.

I am not comfortable with his treatment so I then returned to my parents's home and got separated for 3 months. At that time my husband and my family had a conversation about the continuation of the household but there was no agreement. Finally I chose to sue him in the Pamekasan Religious Court. This is my last step to end my suffering. Moreover when I was beaten, my young child had seen the incident and it drove me traumatized. I have never been to the dukun or kyai to consult with" ${ }^{25}$

\section{Discussion}

Physical domestic violence can result in bleeding, injury, battered and other wound as well as lead to further violence such as intimidation; insulation and totalitarian control on all the whole

${ }^{24} \mathrm{WSH}$, wife of JML, Pamekasan, direct interview, (11 April 2019)

${ }^{25}$ EPS, Pamekasan, direct interview, (1 Agustus 2019) 
aspect of the victim's life. It covers sexuality; material needs; relationships with family, children and friends; and occupation which then cause the high dependency; prolonged trauma; ${ }^{26}$ fright; loss of self-confidence; loss of ability to act; sense of helplessness; severe psychological suffering; and depressed.27

Wives with domestic violence experience generally suffer physical injuries such as bruising, broken bones and chronic disorders that affect their daily functioning. ${ }^{28}$ In above explanation, the data illustrates how they suffered bruises, stab wounds, slashed cheeks exposed to sickles, legs and back bruised bluish. More than that, they suffer psychologically because they feel threatened both physically and mentally.

The findings of this study describe several strategies that those wives employed in protecting their rights. They actively tried to reduce the control and violence of husbands through a series of actions. In short word, they are active in dealing with this case. They dared to put up a fight against their husbands through actively opposing violence, using their resources and strategies, reducing it when it happens, and even ending the suffering. Instead of passive action, this shows strength and courage. Practically, they use three resistance strategies namely internal, external and interpersonal as ways to end suffering.

\section{Internal Resistance Strategy}

The wives use internal resistance strategy when they are emotionally frustrated. They typically do it through religious and personal trust approach. AMN, for example, tried this by reciting prayers she got from kyai whom she consulted with. She fully

${ }^{26}$ Tamara L Kuennen, "Analyzing the Impact of Coercion on Domestic Violence Victims: How Much is too Much," Berkeley J. Gender L. E Just. 22 (2007): $2,1$.

${ }^{27}$ Albert R Roberts, Handbook of Domestic Violence Intervention Strategies: Policies, Programs, and Legal Remedies (New York: Oxford University Press, 2002), 230-232.

${ }^{28}$ Gina Dillon et.al., "Mental and Physical Health and Intimate Partner Violence against Women: A Review of the Literature," International Journal of Family Medicine 2013 (2013). 
believed that the prayers would bring inner peace in coping with violence she experienced.

\section{Strategy of External Resistance}

A wife will typically seek support from outside parties when unable to resolve the violence experience in her internal circle. However, she is still very dependent on the sources of both formal and informal support. This study clearly shows that those wives seek support from parents, siblings, neighbors and police officers. They expect the support of those parties to talk with their husbands in order to stop the violence. In some cases, this strategy works but in others, it does not do so.

$\mathrm{NMH}$, for instance, once asked her neighbors and relatives for help to get emotional support. She got comfortable when they were willing to listen to her stories and complaints. She trusted her neighbors and siblings over her parents-in-law, parents, heads of the Neighborhood Association or RukunTetangga, and the police. As a junior high school graduate, she has no income as well as experience an large access to existing formal institutions and therefore, she chose to talk to to informal institutions. Her strategy works well and her husband stops commiting the domestic violence.

Meanwhile, AMN who studied at Islamic Boarding Schools and universities resolved her violence experience by consulting with kyai as a religious figure. However, when she felt that it hadn't worked well, she also consulted with a shaman who later told her that she was under the control of pellet 'sent' by her husband. She consulted with both parties to help her survived in the hard condition as well as resolve the violence she experienced. The choice that AMN took shows that she tended to use religion and truth as a form of resistance on the violence she experienced and disagrees with. Reciting the prayers from kyai is her effort to surrender her whole affairs to God i addition to find inner peace. She believes that God will determine the best for her between getting divorced and maintaining the household. Until this research is completed, AMN still maintains her marriage relationship.

In addition to prayers from kyai, AMN also got spells to recite from the shaman. Furthermore, she also went to Religious Court as a formal institution to file for divorce although at the end, she chose to 
withdraw the lawsuit simply for the sake of maintaining the household. She did it because of a myth about the shameness of the stigma of a widow that she wanted to avoid. This strategy also works well in reducing the domestic violence committed by her husband.

Another story comes from WSH who chose to visit a shaman. She really hoped and she and her husband would keep maintaining the household eventhough she experienced domestic violence. As an elementary graduate who never studied at Islamic boarding schools, she finally chose to use mystical mantra and ritual that the the saman suggested, namely by immersing her menstrual to her huband's drink. This reflects her submission as well as response on her emotional condition with domestic violence experiencin. This strategy was also succeesful in stopping violence from her husband.

Both NMH and WSH are in the same psychosocial condition due to their educational level and the absence of income which make them vulnerable to any domestic oppression. ${ }^{29}$ They both have experienced violence and cruelty in their household that they finally decided to take a step in order to end their suffering. They consulted the shaman to succeed their mission. On the other hand, the shaman will still get patients' visit as long as the state does nothing in the neighborhood.

The different story is clear from EPS who uses formal rather than informal institutions to stop the violence she experienced. She did it through a formal institution namely the Pamekasan Resort police to keep herself away from her husband and file for divorce to the Pamekasan Religious Court. "I have to do this to get rid of my heart-brokenness and I was succesful in convincing the Religious Court to decide the divorce on Decision Number: 0447/Pdt.G/2017/PA.Pmk. This strategy shows that the wife has also succeeded in stopping violence from her husband.

Interpersonal Resistance Strategies

This study shows the existence of interpersonal strategies carried out by NMH, AMN, WSH and EPS in order to stop the domestic violence they experienced. They left home where they lived

${ }^{29}$ Michele Harway dan James M O'Neil, What Causes Men's Violence against Women? (London: Sage Publications, 1999), 236-237. 
with the violence perpetrators and returned to their to parents' houses. They assumed that leaving the husbands either temporarily or permanently is a way to gain inner peace and physical security.

When NMH, AMN and WSH decided to temporarily leave home then finally come back there again, they hoped their husbands could stop the violence. This strategy is one of the supporting factors beyond the success of those wives in reducing violence. However in the case of EPS, she decided to leave her husband permanently because he had done something very cruel to him. This particularly shows that the wife had reflected on herself and realized that the violence could not be reduced or finished. Thus, EPS considered that leaving home is the only way to end her suffering.

An important note in this finding is the emergence of several resistance strategies that the wives employed to cope with totalitarian power of husbands in the household. They fought against human rights violations that their husbands committed through resistance response to show their discomfort in domestic relations. They did it for maintaining their existence and empowering themselves..$^{30}$

Additionally, these three resistance strategies illustrate the bravery of Madurese women to protect their human rights either offensively or defensively. Offensive resistance, for example, is clear from the case of WSH who aggressively attacked through immersing her menstrual blood in her husband's drinks and countering the hit. Meanwhile, NMH responded the violence of her husband by throwing a plate at him and EPS decided to report the violence to the Police and Religious Courts. As for defensive resistance was obvious from decision of all respondents to leave home where they live with the husbands. These three strategies illustrate the presence of inconvenience situations in household life.

Additionally, Madurese who live in rural and urban areas also believe in mysticism or something unseen. This is particularly true for some mystical purpose in attacking enemies, warding off magic and treating it. If they come to a kyai, the kyai will give them an amulet

\footnotetext{
${ }^{30}$ Naomi Hossain, "Security and the Pathways of Women's empowerment: Findings from a Thematic Synthesis of the Pathways of Women's Empowerment Research," IDS Working Papers 2012, no. 406 (2012): 1-48.
} 
with Islamic nuance, while if they come to a shaman, the shaman will give them a fetish with heresy. ${ }^{31}$

In this context, Madurese have similarities with those in Java because they believe in mystical things. Assimilation and acculturation between local culture and Islam influence the way they live. It is undeniable that the non-Islamic teachings have come first and been adhered before Islam. Cultural and Islamic rituals are interrelated one another and therefore, these non-Islamic traditions are still visible even though the community has adopted and converted to Islam. ${ }^{32}$

In a patient's visit, a shaman will give them salt as a medium to help them curing the diseases they suffer. However sometimes, the medium is also used for resolving cases that the patients deal with, such as domestic life problems, infidelity and trade fraud. Some shamans even believe that the salt only functions in recovering physical ailments as well as resolving household trouble. ${ }^{33}$ This study shows that a wife used menstrual blood immersion in her husband's drink according to the advice of a shaman in which she found it succesful.

The belief of mysticism actually contradicts to a nature of Madurese who are typically devout in living Islamic life. They manifest their obedience to religious teachings at the phrase: "bhuppa', bhabhu', ghuru, and rato" (father, mother, teacher and government leader). ${ }^{34}$ Basically, Islamic teachings are considered well enough to contribute on the formation of Madurese cultural values. ${ }^{35}$ However practically, some people neither fully understand nor enlive these values in Madurese society.

${ }^{31}$ A Latief Wiyata, Carok; Konflik Kekerasan \& Harga Diri Orang Madura (Yogyakarta: LKIS Pelangi Aksara, 2002), 217.

${ }^{32}$ Ali Nurdin, "Komunikasi Magis Dukun (Studi Fenomenologi Tentang Kompetensi Komunikasi Dukun)," Jurnal ASPIKOM 1, no. 5 (2012): 383-402.

${ }^{33}$ Ali Nurdin, Komunikasi Magis Fenomena Dukun di Pedesaan (Yogyakarta: LKiS Pelangi Aksara, 2015), 115.

${ }^{34}$ Latief Wiyata, Carok; Konflik, Kekerasane Harga Diri Orang Madura.

${ }^{35}$ Mien Ahmad Rifai, Manusia Madura: Pembawaan, Perilaku, Etos kerja, Penampilan, dan Pandangan Hidupnya Seperti Dicitrakan Peribahasanya (Yogyakarta: Pilar Media, 2007), hlm. 347. 
The choices of resistance strategy that the wives take in dealing with this violence, according to principles of fiqh, are categorized into two, namely lawful and unlawful. The former consists of reciting prayer from kyai, leaving home, repaying blows and filing for divorce.

God teaches Muslims to pray as clear in al-Baqarah (2): 186

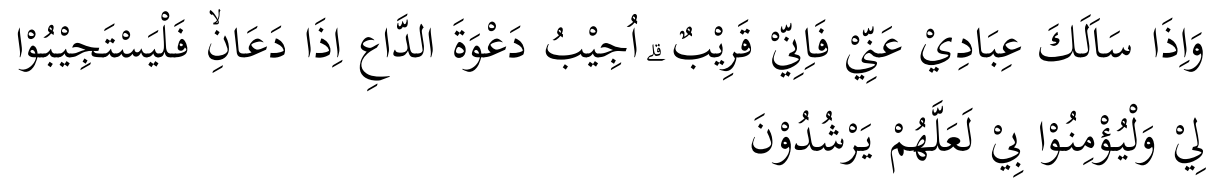

And when My servants ask you, [O Muhammad], concerning $\mathrm{Me}$ - indeed I am near. I respond to the invocation of the supplicant when he calls upon me. So let them respond to me [by obedience] and believe in Me that they may be [rightly] guided.

Meanwhile, other resistance strategies are unlawful because they are not in accordance with the Shariah norms, such as a wife who immerse her menstrual blood in her husband's drink. Although she considered it successful, figh jurisprudence prohibits such practice.

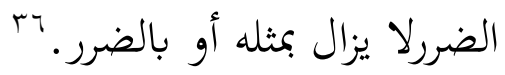

One harm cannot be removed by another harm

In spite of the prohibition in Islamic jurisprudence, anthropologically, she had taken a choice to stop the violence she experienced. She aimed to maintain the marriage relationship despite having to do the disgusting thing. In a legal system that includes legal substance, legal structure and legal culture, this legal culture has an incision namely legal sub-culture. It is a factor with high degree of relevance in discussing case resolution which contains the profit and loss, the needs or interests of what the whole parties want to obtain. ${ }^{37}$

36Shâlih bin Ghânim al-Sadlân, al-Qawâ'id al-Fiqhiyyah al-Kubrâ (al-Riyâdl: Dâr Balinsiyah, 1417 H), 512.

${ }^{37}$ Lawrence M. Friedman, The Legal System: A Social Science Perspective (New York: Russel Sage Foundation, 1975). 
This study shows the legal sub-culture of a wife who experienced household violence. She took this resistance strategy to succeed her mission accordin to her intentions and goals. The same goes on for those who aimed to maintain domestic relations despite having to leave the house temporarily or permanently, countering a blow back, going to a kyai or shaman, or reporting to the police and the Religious Court to sue for her husband's divorce.

Madurese community still chooses the voluntary dispute resolution through negotiation and mediation. ${ }^{38}$ Disputants typically use free bargaining negotiations to struggle for their mission and power in the household. They sought to determine their way of life without State interference. They think that the state will usually apply rigid and win-lose rules in resolving domestic violence.

In this extent, rural and urban communities have different approaches as well as pattern in resolving the case. Rural community usually settles the case through family consultations or village justice institutions, particularly if the disputants come from the same ethnic group. However, sometimes, they settle the case to the State Court for the sake of showing their prestige. If the disputants are from different ethnic group, the will ask help of a mediator from the state apparatus. ${ }^{39}$

Meanwhile, at the same ethnic dispute, those who live in urban areas tend to solve it by referring to local habit rooted in the social system. They usually ask help to a mediator from a regional leader assisted by religious or informal leaders. They prioritize the peace for very first but if it fails and the case led into much hostility, they will submit it to the State court. 40

Any Muslim disputant should pay attention to the Islamuc teaching on how to treat victims humanely. Allah's Messenger (may peace be upon him) gave warning to his followers to stay away from acts of violence and hostility that can damage relations in both social and domestic environment as following;

38Shapiro, Courts: A Comparative and Political Analysis, 6.

39SulistyowatiIrianto, Perempuan di Antara Berbagai Pilihan Hukum (Jakarta: Yayasan Pustaka Obor Indonesia, 2003), 46.

${ }^{40}$ Irianto, 47-48. 


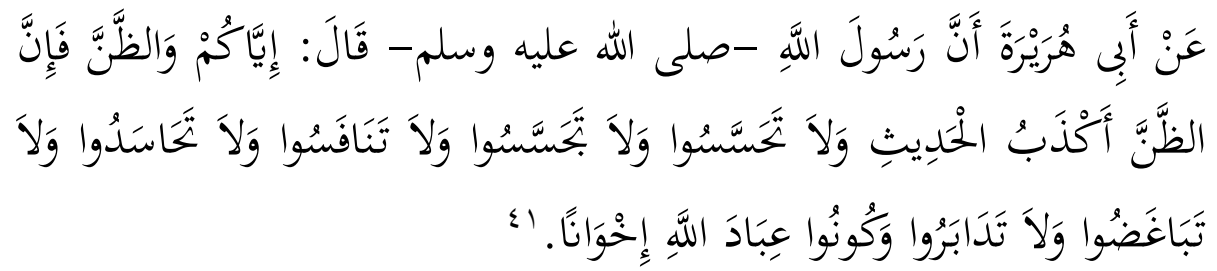

Abu Hurairah (May Allah be pleased with him) said: Allah's Messenger (may peace be upon him) said, "Beware of suspicion, for suspicion is the worst of false tales. Do not look for other's faults. Do not spy one another, and do not practice najsh (means to offer a high price for something in order to allure another customer who is interested in the thing). Do not be jealous of one another and do not nurse enmity against one another. Do not severe ties with one another. Become the slaves of Allah, and be brothers to one another.

Furthermore, Allah's Messenger (may peace be upon him) also forbade a husband to beat his wife as found in the following hadith:

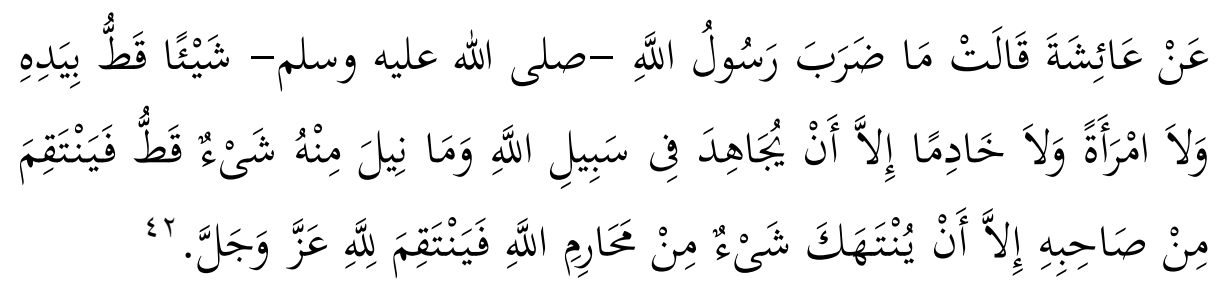

A'isha (May Allah be pleased with her) reported that Allah's Messenger (may peace be upon him) never beat anyone with his hand, neither a woman nor a servant, but only, in the case when he had been fighting in the cause of Allah and he never took revenge for anything unless the

\footnotetext{
${ }^{41}$ Abû al-Husayn Muslim bin al-Hajajâj al-Naysabûrî, Al-Jâmi' al-Shahîh Muslim (Bayrût: Dâr Ihyâ' al-Turâth al-'Arabî, tt.), Jilid VII, 10.

42Muslim bin al-Hajajâj al-Naysabûrî, Jilid IV, 1841.
} 
things made inviolable by Allah were made violable; he then took revenge for Allah, the Exalted and Glorious.

Additionally, Allah's Messenger (may peace be upon him) also condemned a husband who beat his wife as found in the following hadith:

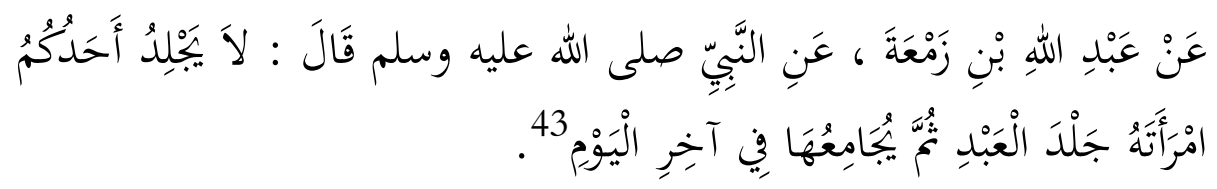

Narrated by 'Abdullah bin Zam`a: The Prophet said: "None of you should flog his wife as he flogs a slave and then have sexual intercourse with her in the last part of the day".

The religious teaching above show Islamic sharia really cares of the victims of violence and therefore, Muslims are obliged to love one another, take care, and avoid any acts of violence, hostility, persecution, humiliation, dropping honor, berating, abusing, stigmatizing or bullying. Perpetrators of domestic violence should no longer seek legitimation for doing the violence mainly from religious teaching.

The state, on the other hand, must be serious in campaigning prevention and taking measure of domestic violence. It cannot simply stand while waiting the victims to report the violence they experience. Instead, they should be proactive to prevent domestic violence through a variety of approaches, such as strengthening individual knowledge and skills, promoting public education, fostering coalitions and networks, changing organizational practices and influencing policies and laws. ${ }^{44}$ The seriousness of the state,

${ }^{43}$ Muhammad bin Ismâ'il Abû Abdullah al-Bukhârî, al-Ṣahîh al-Bukhârî (alQâhirah: Dâr al-Sya'b, 1987), Jilid VII, 42.

${ }^{44}$ Rachel Davis, Lisa Fujie Parks, and Cohen, Sexual Violence and the Spectrum of Prevention: towards a Community Solution (Enola PA: National Sexual Violence Resource Center, 2006), 7. 
afterward, must be well supported by awareness of society not to justify any violence act on the excuse of religion and culture.

\section{Conclusion}

Victims of domestic violence in Madura have shown their courage by carrying out some conscious and active strategies to protect their human rights. The experience of victims in carrying out this strategy deserves appreciation because women are no longer subordination to men. They have sought to protect themselves internally, externally and interpersonally. The four cases of domestic violence above show how few victims of domestic violence reported violence experience to formal institutions. Some of them felt more comfortable to choose informal institutions. This research suggests that the State establish an anti-violence institution at the village/ kelurahan level to prevent, reduce and stop violence against wives. However, this institution must synergize with community and religious leaders so that the resolution of violence is not only before the court but also based on local wisdom.

\section{Bibliography}

Abdullah, Amin. Mencari Islam: Studi Islam dengan BerbagaiPendekatan. Yogyakarta: Tiara Wacana, 2000.

Abraham, Margaret. Speaking the Unspeakable: Marital Violence among South Asian immigrants in the United States. New Brunswick, New Jersey and London: Rutgers University Press, 2000.

Anderson, Kim M, Lynette M Renner, dan Tina S Bloom. "Rural Women's Strategic Responses to Intimate Partner Violence." Health Care for Women International 35, no. 4 (2014): 423-41.

Barrett, Jerome T, dan Joseph Barrett. A History of Alternative Dispute Resolution: The Story of a Political, Social, and Cultural Movement. San Francisco: John Wiley \& Sons, 2004.

Bukhârî, Muhammad bin Ismâ'ilAbû Abdullah al-. al-Ṣahîh al-Bukhârî. al-Qâhirah: Dâr al-Sya'b, 1987.

Cresswel, Jhon W. "Penelitian Kualitatif dan Desain Riset (edisi Bahasa Indonesia)." Yogyakarta: Pustaka Pelajar, 2015.

Davis, Rachel, Lisa Fujie Parks, dan Cohen. Sexual Violence and the Spectrum of Prevention: towards a Community Solution. Enola PA: National Sexual Violence Resource Center, 2006. 
Dillon, Gina, Rafat Hussain, Deborah Loxton, and Saifur Rahman. "Mental and Physical Health and Intimate Partner Violence against Women: A Review of the Literature." International Journal of Family Medicine 2013 (2013).

Friedman, Lawrence M. The Legal System: a Social Science Perspective. New York: Russel Sage Foundation, 1975.

Harway, Michele, dan James M O'Neil. What Causes Men's Violence against Women? London: Sage Publications, 1999.

Hossain, Naomi. "Security and the Pathways of Women's Empowerment: Findings from a Thematic Synthesis of the Pathways of Women's Empowerment Research." IDS Working Papers 2012, no. 406 (2012): 1-48.

Irianto, Sulistyowati. Perempuan di Antara Berbagai Pilihan Hukum. Jakarta: Yayasan Pustaka Obor Indonesia, 2003.

Khaleed, Badriyah. Penyelesaian Hukum KDRT: Penghapusan Kekerasan dalam Rumah Tangga dan Upaya Pemulihannya. Yogyakarta: Pustaka Yustisia, 2015.

Komnas, HAM. “Laporan Tahunan Komnas HAM 2016: Pemenuhan Hak Kelompok Minoritas dan Rentan di Indonesia." Jakarta: Komnas HAM, 2017.

Kuennen, Tamara L. "Analyzing the Impact of Coercion on Domestic Violence Victims: How Much is Too Much." Berkeley J. Gender L. E Just. 22 (2007): 2.

Miles, Matthew B, dan A Michael Huberman. "Analisis Data Kualitatif. transl Tjetjep Rohendi Rohidi." Jakarta: Penerbit Universitas Indonesia, 1992.

Moleong, Lexy J. Metodologi Penelitian Kualitatif. Bandung: Remadja Karya, 1989.

Morgan, Mandy, and Tony Mattson. “Dignity, Diversity, and Resistance: A Bicultural, Community-Led Approach to Transforming Social Responses to Domestic Violence in Aotearoa New Zealand." Australian Community Psychologist 29, no. 2 (2018). 
Muslim bin al-Hajjâj al-Naysabûrî, Abû al-Husayn. Al-Jâmi' al-Ṣahîh Muslim. Bayrût: DârIhyâ' al-Turâth al-'Arabî, tt.

Nader, Laura, dan Harry F Todd. The Disputing Process: Law in Ten Societies. New York: Columbia University Press, 1978.

Nifosi-Sutton, Ingrid. The Protection of Vulnerable Groups under International hHman Rights Law. New York: Routledge, 2017.

Nurdin, Ali. "Komunikasi Magis Dukun (Studi Fenomenologi tentang Kompetensi Komunikasi Dukun)." Jurnal ASPIKOM 1, no. 5 (2012): 383-402.

- - - Komunikasi Magis Fenomena Dukun di Pedesaan. Yogyakarta: LKiS Pelangi Aksara, 2015.

Perempuan, Komnas. "Korban Bersuara, Data Bicara Sahkan RUU Penghapusan Kekerasan Seksual sebagai Wujud Komitmen Negara Catatan Kekerasan terhadap Perempuan Tahun 2018." Jakarta, 6 Maret 2019.

Riddell, Thelma, Marilyn Ford-Gilboe, and BeveryLeipert. "Strategies Used by Rural Women to Stop, Avoid, or Escape from Intimate Partner Violence." Health Care for Women International 30, no. 12 (2009): 134-59.

Rifai, Mien Ahmad. Manusia Madura: Pembawaan, Perilaku, Etos Kerja, Penampilan, dan Pandangan Hidupnya seperti Dicitrakan Peribahasanya. Yogyakarta: Pilar Media, 2007.

Roberts, Albert R. Handbook of Domestic Violence Intervention Strategies: Policies, Programs, and Legal Remedies. New York: Oxford University Press, 2002.

Sadlân, Shâlih bin Ghânim al-. al-Qawâ'id al-Fiqhiyyah al-Kubrâ. alRiyâdl: Dâr Balinsiyah, 1417.

Sayem, Amir Mohammad, dan Mohammad Aftab Uddin Khan. "Women's strategic responses to intimate partner violence: A study in a rural community of Bangladesh." Asian Social Work and Policy Review 6, no. 1 (2012): 23-39.

Scott, James C. Weapons of the Weak: Everyday Forms of Peasant Resistance. New Haven and London: Yale University Press, 1985.

Shapiro, Martin. Courts: A Comparative and Political Analysis. London: University of Chicago Press, 1981.

St Vil, Noelle M, Bushra Sabri, Vania Nwokolo, Kamila A Alexander, and Jacquelyn C Campbell. "A Qualitative Study of Survival 
Fahruddin Ali Sabri, ArifWahyudi, Fatekhul Mujib

Strategies Used by Low-Income Black Women who Experience Intimate Partner Violence." Social Work 62, no. 1 (2017): 63-71.

Strauss, Anselm, and Juliet Corbin. "Dasar-dasar Penelitian Kualitatif." Yogyakarta: Pustaka Pelajar, 2003.

Wiyata, A Latief. Carok; Konflik Kekerasan \& Harga Diri Orang Madura. Yogyakarta: LKIS Pelangi Aksara, 2002. 